\title{
ANATOMICAL PECULIARITIES OF THE CERVICAL PART OF THE VAGUS NERVE DURING FETAL AND EARLY NEONATAL PERIODS OF ONTOGENESIS
}

\author{
O.M. Slobodian, L.M. Herasym
}

Higher State Educational Establishment of Ukraine "Bukovinian State Medical University", Chernivtsi

Key words: vagus nerve, anatomy, morphometry, perinatal period.

Clinical and experimental pathology. Vol.18, №4 (70). P.80-84.

DOI:10.24061/17274338.XVIII.4.70.2019.295

E-mail: top_anatomy @ bsmu.edu.ua
Anatomical investigations of the vagus during the perinatal period enable to determine morphological aspects of individual changeability, which will form the basis for detection of different variants of structure and developmental defects during the postnatal period of ontogenesis. They can be applied during development of new surgical approaches and methods in neonates and infants.

Objective - detection of anatomical peculiarities of the cervical part of the vagus nerve during fetal and early period of human ontogenesis.

Materials and methods. The study was conducted on 50 specimens of dead fetuses (from 4 to 10 months) and 9 neonates (5 isolated organ complexes in particular) by means of adequate anatomical methods: macro-dissection, making topographic-anatomical sections, morphometry, and statistical analysis. The data obtained were statistically processed by means of the licensed program RStudio.

Results. Topography of the vagus nerve in the cervical portion during the perinatal period is found to be changeable.

Conclusions. Topography of the vagus nerve in the portion of the neck during the perinatal period of ontogenesis is changeable. In the upper third of the neck the vagus nerve adjoins the anterior-lateral surface of the internal carotid artery. In the middle third it borders on the lateral or anterior-lateral wall of the common carotid artery. In the lower third it borders on the posterior-medial or lateral wall of the internal jugular vein. During the perinatal period the diameters of the right and left vagus nerves are characterized by the two periods of an accelerated development (from the $4^{\text {th }}$ to the $6^{\text {th }}$ month of the intrauterine development and from the 9th month to the neonatal period 4), and the period of relatively slow development (from the 6th month to the $9^{\text {th }}$ month of the intrauterine development). During the perinatal period the upper and lower branches of the upper laryngeal nerve and external carotid artery are the walls of the cervical triangle, which serves as an additional topographic-anatomical sign during surgery performed on infants.

\section{Ключові слова: блукаючий нерв, анатомія, морфометрія, перинатальний nеріод.}

\section{АНАТОМІЧНІ ОСОБЛИВОСТІ ШИЙНОЇ ЧАСТИНИ БЛУКАЮЧОГО НЕРВА У ПЛОДОВОМУ ТА РАННЬОМУ НЕОНАТАЛЬНОМУ ПЕРІОДАХ ОНТОГЕНЕЗУ}

\section{О.М. Слободян, Л.М. Герасим}

Анатомічні дослідження блукаючих нервів в перинатальному періоді дозволять визначити морфологічні аспекти індивідуальної мінливості, які будуть слугувати основою для встановлення різних варіантів будови $і$ вад їх розвитку в постнатальному періоді онтогенезу, а також можна буде використовувати під час розробки нових хірургічних доступів і прийомів у новонароджених та дітей раннього віку.

Мета роботи - встановлення анатомічних особливостей шийноӥ частини блукаючого нерва у плодовому та ранньому періоді онтогенезу.

Матеріали та методи. Дослідження виконано на 50 препаратах трупів плодів (від 4 до 10 місяиів) та 9 новонароджених (зокрема, 5 ізольованих органокомплексів) за допомогою адекватних анатомічних методів: макропрепарування, виготовлення топографоанатомічних зрізів, морфометріі, статистичного аналізу. Статистичний аналіз отриманих даних проводили за допомогою ліцензованої програми RStudio.

Результати. Встановлено, що топографія блукаючого нерва в діляниі шиї в перинатальному періоді онтогенезу мінлива.

Висновки. У верхній третині шиї блукаючий нерв примикає до передньобічної поверхні внутрімньої сонної артерії, у середній - до бічної або передньобічної стінки загальної сонної артерії, у нижній - до задньомедіальної або бічної стінки внутрішньої яремної вени. Упродовж перинатального періоду для діаметра правого і лівого блукаючого нерва є характерно два періоду прискореного розвитку (з 
4-го по 6-й місяцุь внутрішньоутробного розвитку та з 9-го місяия по період новонародженості) і період відносно сповільненого розвитку (з 6-го по 9-й місяиьь внутрішньоутробного розвитку). У перинатальному періоді верхня $і$ нижня гілки верхнього гортанного нерва та зовнішня сонна артерія є стінками шийного трикутника, щи слугує додатковою топографоанатомічною ознакою під час виконання хірургічних втручань у дітей раннього віку.

\begin{tabular}{ll}
\hline \hline Ключевые слова: & АНАТОМИЧЕСКИЕ ОСОБЕННОСТИ ШЕЙНОЙ ЧАСТИ БЛУЖДАЮЩЕГО НЕРВА В \\
бЛУжд ающий & ПЛОДНОМ И РАННЕМ НЕОНАТАЛЬНОМ ПЕРИОДАХ ОНТОГЕНЕЗА
\end{tabular}

нерв, анатомия, морфометрия, перинатальный период.

Клиническая и экспериментальная патология Т.18, №4 (70). C.80-84.

\section{А.М. Слободян, Л.М. Герасим}

Анатомические исследования блуждающих нервов в перинатальном периоде позволяют определить морфологические аспекть индивидуальной изменчивости, которые будут служить для установления разных вариантов строения и патологий развития в постнатальном периоде онтогенеза, пакже можно будет использовать во время разработки новых хирургических доступов и приёмов у новорожденных и детей раннего возраста.

Цель работы - установить анатомические особенности шейной части блуждающего нерва в плодовом и раннем периодах онтогенеза.

Материалы и методы. Исследование проведено на 50 препаратах трупов плодов (от 4 до 10 месячев) и 9 новорожденных (в частности, 5 изолированных органокомплексов) с помощью адекватных анатомических методов: макропрепарирование, изготовление топографоанатомических срезов, морфометрии, статистического анализа. Статистический анализ полученных данных проводили с помощьюю лицензированной программы RStudio.

Результаты. Установлено, что топография блуждающчего нерва в участке шеи в перинатальном периоде онтогенеза изменчива.

Выводы. В верхней трети шеи блуждающий нерв примыкает к переднебоковой поверхности внутренней сонной артерии, а в средней - к боковой или к переднебоковой стенки сонной артерии, в нижней - к заднемедиальной или боковой стенке внутренней яремной вень. Во время перинатального периода для диаметра правого и левого блуждающего нерва характерно два периода ускоренного развития (с 4-го по 6-й месяи внутриутробного развития и с 9-го месяиа по период новорожденности) и период относительного замедленного развития (с 6-го по 9-й месяи внутриутробного развития). В перинатальном периоде верхняя и нижняя ветки верхнего гортанного нерва и внешняя сонная артерия являются стенками шейного треугольника, что служит дополнительным топографоанатомическим признаком во время хирургических операчий у детей раннего возраста.

\section{Introduction}

Congenital developmental defects take an important place among topical issues of health care under modern conditions of deteriorated ecological situation, spread of bad habits and infectious diseases, and considerable qualitative increase of prenatal diagnostics. Occurrence of congenital developmental defects in different countries ranges within 22,7-50\%, and among dead children - 230$250 \% 0$. Perinatal death with congenital developmental defects is high (23-25\%), and stillbirth is $11-13 \%[1,2]$. Therefore, the main current task of perinatology is development of effective methods of prevention and early prenatal diagnostics of congenital pathology [3].

Anatomy of the vagus nerves of the neck is sufficiently described in adults. Though, the issues concerning establishment of their topographic-anatomical peculiarities and detection of organometric parameters during the prenatal period are found in an insufficient number of scientific publications. Moreover, the data available are disputable and of a fragmentary character [49]. Anatomical studies of the vagus nerves during the perinatal period will enable to determine morphological aspects of individual changeability. They will form the basis to find different variants of the structure and developmental defects during the postnatal period of ontogenesis. They will also be used in elaboration of new surgical approaches and methods applied for neonates and infants [10-14].

Objective to determine anatomical peculiarities of the cervical part of the vagus nerve during the fetal and early neonatal periods of ontogenesis.

\section{Materials and methods}

The study was conducted on 50 specimens of dead fetuses (from 4 to 10 months) and 9 neonates (5 isolated organ complexes in particular) without external signs of anatomical deviations or abnormalities, and without vivid microscopic deviations from the normal structure of the cardio-vascular system. The following methods of investigation were used: macro-dissection, making topographic-anatomical sections, morphometry, and statistical analysis. The data obtained were statistically processed by means of the licensed program RStudio. 
The values with $\mathrm{p}<0,05$ were considered to be statistically significant.

The study was conducted according to the major principles of the Declaration of Helsinki by the World Medical Association concerning ethical principles for medical research involving human subjects (1964-2000) and the Order of the Ministry of Health of Ukraine № 690, dated 23.09.2009. Scientific research is a fragment of a comprehensive planned initiative scientific-research study of M.G.Turkevych Department of Human Anatomy and the Department of Anatomy, Clinical Anatomy and Operative Surgery at HSEE of Ukraine "Bukovinian State Medical University": "Peculiarities of Morphogenesis and Topography of the Organs and Systems during the Prenatal and Postnatal Periods of Ontogenesis" (State Registration № 0115U002769).

\section{Results and discussion}

The cervical part of the vagus nerve is located in the caudal direction from the stylohyoid muscle to the point of passing through the upper opening of the thoracic cavity. The vagus nerve is contained in the major vascular-nervous bundle of the neck in addition to other components as carotid arteries and internal jugular vein. The major vascular-nervous bundle of the neck is covered by the parietal layer of the intracervical fascia.

During the perinatal period of ontogenesis the vagus nerve usually adjoins the anterior-lateral surface of the internal carotid artery in the upper third of the neck. Only in $31 \%$ of observations it extends at the distance of 1,2-1,7 $\mathrm{mm}$ from the lateral margin of the internal carotid artery. This ratio is found mostly in the second trimester of the intrauterine development. On the level of the middle portion of the upper third of the neck and on the anterior surface of the internal carotid artery the vagus nerve extends the upper laryngeal nerve dividing into two branches: upper and lower. The upper branch of the upper laryngeal nerve passes in the ventral direction turning the anterior surface of the external carotid artery. After that it extends practically to the middle of the distance between the lower margin of the submandibular salivary gland and hyoid bone. The lower branch of the upper laryngeal nerve passes obliquely from backward to forward. It has a caudal direction. During the perinatal period of ontogenesis in front of the point of the common carotid artery bifurcation the lower branch of the upper laryngeal nerve usually extends ( $78 \%$ cases. In other cases $(22 \%)$ it passes cranially from the point of division of the common carotid artery 3,0-5,0 $\mathrm{mm}$ in front from the external and internal carotid arteries. Such topographic-anatomical position between the branches of the upper laryngeal nerve and external carotid artery can serve as an additional sign able to differentiate external and internal carotid arteries during the perinatal period of ontogenesis. In our opinion, the following topographic-anatomical portion of the neck should be reasonably isolated. It is a triangle with the following sides: the upper border - the upper branch of the upper laryngeal nerve, the lateral side - the lower branch of the upper laryngeal nerve, and the middle side - external carotid artery.

The vagus nerve in the upper part of the carotid triangle adjoins the lateral wall of the common carotid artery, in the lower part the nerve passes onto the anteriorlateral arterial wall.

In the lower third of the neck the vagus nerve adjoins the posterior-medial wall of the internal jugular vein. Caudally the vagus nerve adjoins its lateral wall.

Usually the diaphragmatic and vagus nerves extend parallel. At the same time, the vagus nerve is located in the middle. Only in one case (the fetus $190,0 \mathrm{~mm}$ of the parietal-calcaneal length (PCL)) a variant of location of these nerves was detected: from the point of beginning the diaphragmatic nerve is located in the middle from the vagus nerve.

During the perinatal period of ontogenesis the diameter of the right vagus nerve increases from $0,62 \pm 0,09$ $\mathrm{mm}$ (4-month fetuses) to $1,9 \pm 0,03 \mathrm{~mm}$ (neonatal period) (Fig. 1), the diameter of the left vagus nerve increase from

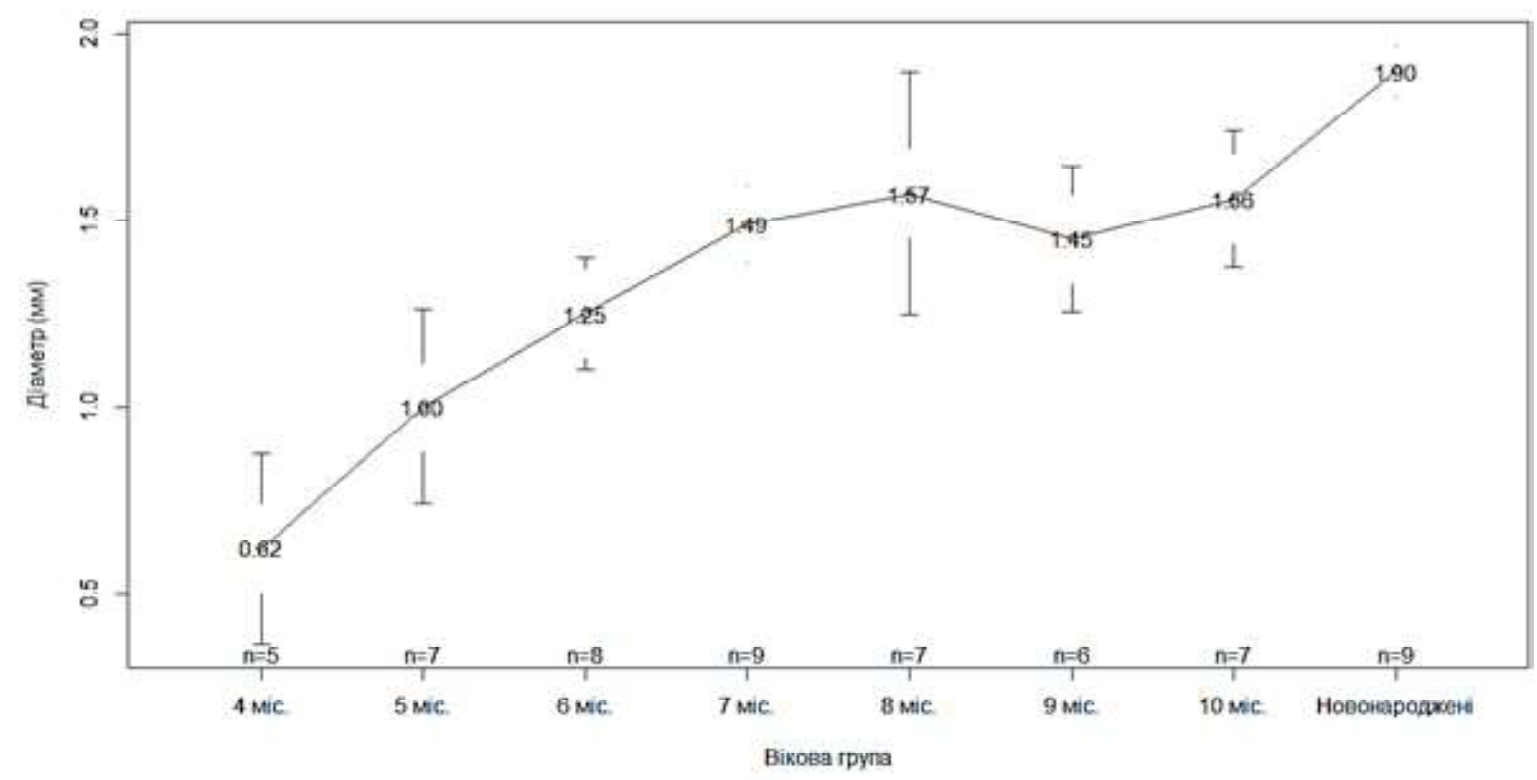

Figure 1. Diagram of the right vagus nerve diameter during the perinatal period of ontogenesis 
$0,48 \pm 0,09 \mathrm{~mm}$ to $1,57 \pm 0,04 \mathrm{~mm}$ (Fig. 2). The diameters of the right and left vagus nerves increase from the 4 th to the 6th month of the intrauterine development, and from the 9th month to the neonatal period. In the period from the 6th to the 9th month of the intrauterine development these parameters inconsiderably increase.

In the result of Student test to compare average values in the diameters of the right and left vagus nerves, p-value $<0,05$ is specific for the age groups "7 months", "9 months", "10 months" and "neonates", which is indicative of a considerable difference of the mean values of these diameters.

By the results of Conover-Iman test for the right and left vagus nerves the difference of medians for all the age pairs is statistically significant, except the following pairs: for the right vagus nerve - "4 months - 5 months", "5 months - 6 months", "7 months -8 months", "7 months -9 months", "7 months - 10 months", "8 months - 9 months", "8 months - 10 months", "9 months - 10 months", for the left vagus nerve - "5 months - 6 months", "5 months - 7

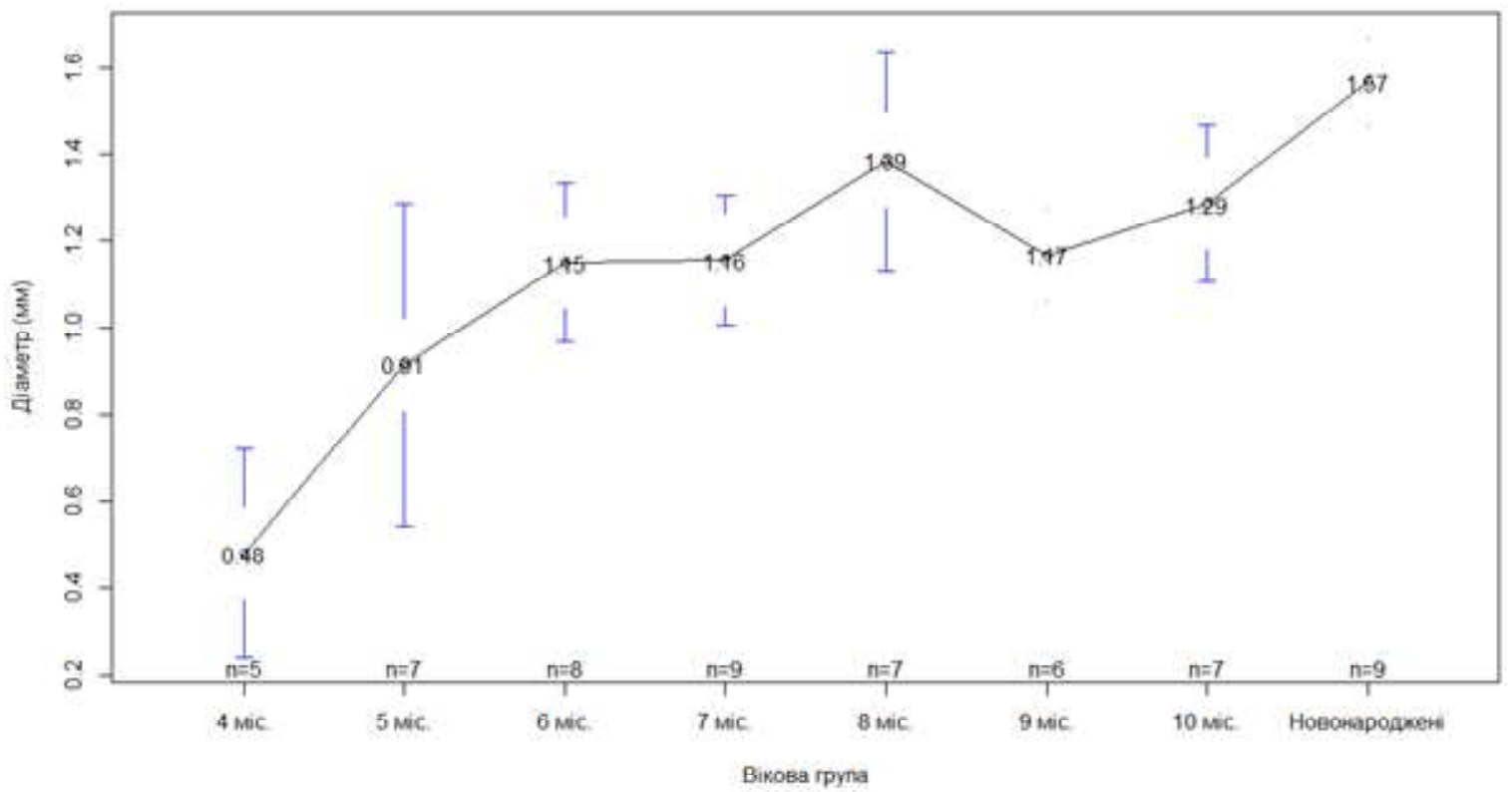

Figure 2. Diagram of the left vagus nerve diameter during the perinatal period of ontogenesis

months", "5 months - 9 months", "6 months - 7 months", "6 months - 8 months", "6 months - 9 months", "6 months - 10 months", "7 months - 10 months", "7 months - 9 months", "8 months - 9 months", "9 months - 10 months", "8 months - neonates".

\section{Conclusions}

1.Topography of the vagus nerve in the portion of the neck during the perinatal period of ontogenesis is changeable. In the upper third of the neck the vagus nerve adjoins the anterior-lateral surface of the internal carotid artery. In the middle third it borders on the lateral or anterior-lateral wall of the common carotid artery. In the lower third it borders on the posterior-medial or lateral wall of the internal jugular vein.

2.During the perinatal period the diameters of the right and left vagus nerves are characterized by the two periods of an accelerated development (from the 4th to the 6th month of the intrauterine development and from the 9th month to the neonatal period 4 ), and the period of relatively slow development (from the 6th month to the 9th month of the intrauterine development).

3.During the perinatal period the upper and lower branches of the upper laryngeal nerve and external carotid artery are the walls of the cervical triangle, which serves as an additional topographic-anatomical sign during surgery performed on infants.

\section{Perspectives of further studies}

Клінічна та експериментальна патологія. 2019. Т.18, №4(70)
Investigation of topographic-anatomical peculiarities of the major vascular-nervous cervical bundle components, and the vagus nerve in particular, during all the periods of the postnatal ontogenesis seems to be reasonable.

Список літератури:

1.Приймак СГ. Використання методів профілактики вроджених вад розвитку плода. Неонатологія, хірургія та перинатальна медицина. 2013;3(4):89-91.

2.Григорьєва ОВ, Рибалка АМ, Заболотнов ВО. Профілактика і діагностика вроджених вад розвитку плода. Вісник наукових досліджень. 2005;4:27-9.

3.Ахтемійчук ЮТ, Слободян ОМ, Лаврів ЛП. Пренатальний розвиток органів і структур організму. Експериментальна i клінічна медицина. 2014;3:18-21.

4.Ахтемійчук ЮТ. Актуальність наукових досліджень в галузі перинатальної анатомії. Неонатологія, хірургія та перинатальная медицина. 2012;2(1):15-21.

5.Лехан ВМ, Гінзбург ВГ. Перинатальна смертність в Україні: досягнення та проблеми. Україна. Здоров'я нації. 2012; $1: 15-25$

6.Лихачев СА, Черненко НИ. Ультразвуковое исследование блуждающего нерва. Неврологический журнал. 2010;15(2):359.

7.Cheng G, Zhu H, Zhou X, Qu J, Ashwell KW, Paxinos G. Development of the human dorsal nucleus of the vagus. Early Hum Dev. 2008;84(1):15-27. doi: 10.1016/j.earlhumdev.2007.01.012

8.Giovagnorio F, Maftinoli C. Sonography of the cervical vagus nerve normal appearance and abnormal findings. AJR Am J Roentgenol. 2001;176(3):745-9. doi: 10.2214/ajr.176.3.1760745

9.Haller JM, Iwanik M, Shen FH. Clinically Relevant Anatomy of Recurrent Laryngeal Nerve. Spine (Phila Pa 1976). 2012; 37(2):97-100. doi: 10.1097/BRS.0b013e31821f3e86

10.Sakamoto Y. Classification of pharyngeal muscles based on ISSN 1727-4338 https://ww.bsmu.edu.ua 
innervations from glossopharyngeal and vagus nerves in human. Sur Radiol Anat. 2009;31(10):755-61. doi: 10.1007/s00276-009-05169

11.Simon E, Mertens P. Anatomie fonctionnelle des nerfs glossopharyngien, vague, accessoire et hypoglosse Functional anatomy of the glossopharyngeal, vagus, accessory and hypoglossa cranial nerves. Neurochirurgie. 2009;55(2):132-5. doi: 10.1016/ j.neuchi.2009.01.018

12.Benouaich V, Porterie J, Bouali O, Moscovici J, Lopez R. Anatomical basis of the risk of injury to the right laryngeal recurrent nerve during thoracic surgery. Surg Radiol Anat. 2012; 34(2):509-12. doi: 10.1007/s00276-012-0946-7

13.Dionigi G, Chiang FY, Rausei S, Wu CW, Boni L, Lee KW, et al. Surgical anatomy and neurophysiology of the vagus nerve $(\mathrm{VN})$ for standardised intraoperative neuromonitoring (IONM) of the inferior laryngeal nerve (ILN) during thyroidectomy. Langenbecks Arch Surg. 2010;395(7):893-9. doi: 10.1007/s00423-010-0693-3

14.Miyake N, Hayashi S, Kawase T, Cho BH, Murakami G, Fujimiya M, et al. Fetal Anatomy of the Human Carotid Sheath and Structures In and Around It. Anat Rec (Hoboken). 2010;293(3):43845. doi: 10.1002/ar.21089

\section{References:}

1.Priymak SG. Vykorystannia metodiv profilaktyky vrodzhenykh vad rozvytku ploda [The using of prevention of fetus congenital defects]. Neonatology, Surgery and Perinatal Medicine. 2013;3(4):89-91. (in Ukrainian)

2. Hryhor'ieva OV, Rybalka AM, Zabolotnov VO. Profilaktyka i diahnostyka vrodzhenykh vad rozvytku ploda [Prevention and diagnosis of congenital malformations of the fetus]. Bulletin of Scientific Research. 2005;4:27-9. (in Ukrainian)

3.Akhtemiychuk YuT, Slobodian OM, Lavriv LP. Prenatal'nyi rozvytok orhaniv i struktur orhanizmu [Prenatal growth of organs and structures]. Experimental and Clinical Medicine. 2014;3:1821. (in Ukrainian)

4.Akhtemiychuk YuT. Aktualnist naukovykh doslidzhen v haluzi perynatalnoi anatomii [Topicality of the scientific research in the field of perinatal anatomy]. Neonatology, Surgery and Peri-

\section{Відомості про авторів:}

Слободян О. М.- д. мед. н., професор, завідувач кафедри анатомії, топографічної анатомії та оперативної хірургії Вищого державного навчального закладу України "Буковинський державний медичний університет", м. Чернівці.

Герасим Л. М. - асистент кафедри хірургічної стоматології та щелепно-лицевої хірургії Вищого державного навчального закладу України "Буковинський державний медичний університет", м. Чернівці.

\section{Сведения об авторах:}

Слободян А. Н. - д. мед. н., профессор, заведующий кафедры анатомии, топографической анатомии и оперативной хирургии Высшего государственного учебного учреждение "Буковинский государственный медицинский университет", г. Черновцы.

Герасим Л. Н. - ассистент кафедры хирургической стоматологии и челюстно-лицевой хирургии Высшего государственного учебного учреждение "Буковинский государственный медицинский университет", г. Черновцы.

\section{Information about the authors:}

Slobodian O. M. - doctor of medical sciences, professor, chief of the department of anatomy, topographic anatomy and operative surgery of the Higher State Educational Establishment of Ukraine "Bukovinian State Medical University", Chernivtsi. Herasym L. M. - assistant department of surgical dentistry and maxillofacial surgery of the Higher State Educational Establishment of Ukraine "Bukovinian State Medical University", Chernivtsi. 